\title{
「遁花秘訣」原書の和訳 (1)
}

村山 七 郎*

序交

村山七郎教授の「遁花秘訣原書の和訳」が 本誌上に発表されるに当って一言, 「遁花秘 訣」の医学更ないし日本交化史上の意義を述 心゙て括く，馬場佐十郎が文政 3 年 (1820), 函 館に执いて訳したといわれる「遁花秘訣」は ジェンナーの牛痘接種法をわが国に紹介した 最初であるとともにロシア語翻訳の嚆矢であ った。

その原本は千島エトロフ島の番人小頭てし ていた中川五郎治がロシア人に捕えられて，

5 年間もシベリアの諸地を流浪するあいだに 入手して文化 9 年 (1812) 飞持ちか觉ったも のであった。それが 1803年露都ペテルブルグ で発行された小冊であることは分っていたが， 日本に残存していることが不明なために今日 までその詳細が知られなかった。村山教授は 最近にソ連に旅行して原本をみつけたので, ここにその全訳を揭げるという次第である。
ジェンナーの牛痘法が 鎖国下の日本に初め て根を下万すのは嘉永 2 年 (1849) 長崎に拉 いてであって，そこから忽ら全国に広がって いったが，その 30 年も前にロシア語から訳本 がつくられ，また五郎治の種痘法が北海道や 秋田に扔いて若干特こなわれたことは日本の 医学实でもっとも興味ある一節である。

「遁花秘訣」写本はいま私の手許に2 種の コピーがあり，その内容を嘉永 3 年に利光仙 庵が「魯西亜牛痘全書」と題して出版したも のも幸いに蔵することができた。

いま村山教授の訳文を得て，江戸時代きっ ての語学の鬼才馬場佐十郎がどれだけ正確に ロシア語を読んだか知りらるのは大きい喜び である。また牛痘接種法の実施は江戸時代末 期の洋医学の発展, したがって順天堂の歴史 にも大きい役割をなした。ここで私の「佐藤 泰然伝」をこの際 2 回だ忖休んで，村山教授 の貴重な訳文を載せることにした。

小川 鼎 三**

\section{訳 者の序}

ここに読者の前に提供されるこの訳文は，馬 場佐十郎が1820年に出した日本に和ける最初の 牛痘法交献・遁花秘訣・のロシア語原書

*順天堂大学教授 (ドイツ語, 言語学)

**順天堂大学教授 (医实学)
Способ избавиться совершенно от оспенной заразы посредством всеобщего прививания коровьей оспы. Ст. Петербург 1803.

「牛痘普及により天然痘を完全にのがれる方 法」（ペテルブルグ, 1803年）の全訳である.

この原書についてわが国で最初に紹介したの は拙論1)で女る。私の橎訳はこの原書の, 日本 に怙ける 2 回目のものであり, 第 1 回のものか 
ら 145 年をへだてている.

馬場佐十郎の訳「遁花秘訣」は函館市立図書 館に写本が 1 部めり, 小川鼎三教授の手許にも 別の写本が 1 部岕るが，いずれも原本ではな く，何回からつし直されたものである.

利光仙庵が1830年ころ長崎で入手したものは 写本であったか刊本であったか，い虫のところ 不明であるが，そのいずれであったとしても， 馬場が1820年に出したものそのものか，又はそ れに甚だ近いものであったと断定できる。利光 仙痷が1850年に鲁西覀牛痘全畫の名のもとに遁 花秘訣を刊行したさい馬場の訳に手を加它たと 思われる部分は，ロシア語原書を手にする私に とって可成り明瞭であり，従ってこうした部分 学除けば，1820年に出された遁花秘訣の原形は 鲁西覀牛痘全書から復元できるはずである。殊 に函館市立図書館本, 小川鼎三教授の手許に㐫 る写本を参考にすれば, 1820年の原本の姿は, ほぼ完全に復元できるだろう。しかしいま私は その仕事を行ら余裕をもたないしまたその緊 急の必要性もみとめられない。私は, 医史学徒 が拙訳と鲁西亜牛痘全書とを比較して, 馬場佐 十郎の仕事の偉大さを理解することを希望する のスである。

ここでロシアに拈ける天然痘, 人痘, 最初の 牛痘接種について, S. B. ドゥブロウィンス キーのめらわした「天然痘と種痘」

С.Б. Дубровинский. Оспа и оспопри вивание Москва 1959.

から，次の記事を紹介したい。

ロシアでは17世紀以前の天然痘流行について は正確な記録はない.17世紀にロシア人が天然 痘をシベリヤにはこび，土民の約 3 分の 1 がそ のために死亡した. 18世紀にはロシアでは毎年 約 50 万人（人口の約 $1.5 \%$ ) が天然痘で死亡し た.19世紀，20世紀に入っても天然痘はロシア から消究ず，1898年には15万人，1910年には16 万 5 千人が羅病した。

第一次大戦前の国勢調査によると盲者が32万 人であったが，このうち4万人 (12.5\%) は天
然痘によるものであった。

ロシアでは18世紀後半に人痘接種が実施され 出した。ペートル二世が天然痘で亡くなってか ら，宮廷では人痘接種に関心を払うようになっ た。 ラトヴィアの医師シュレニウスは1756年に 1,000名に人痘接種を行った. 英国の Dimsda11 がペテルブルグに招かれてから人痘接種は拡ま った。エカテリナ二世と皇太子も彼の手で人痘 を種觉られた。しかし1768一1779年にペテルブ ルグでは 1,844 名が接種をうけただけである。

1801年にロシアで始めてジェンナーの方法に よってモスクワの児童養育院（喋子収容所）で モスクワ大学のイェ・ムーヒン教授が牛痘を接 種した。侍医や外科医, 養育院評議員たちが接 種の場に立ら希った。接種を受けた最初の览童 はワクチーノフ（ワクチンから）といら名（ワ クチンというのはラテン語ワッカ「牝牛」から つくられた術語）を与えられ，貴族の位を与え られ，年金やその他の特権が与它られた。

このような状況のもとに, 遁花秘訣の原本は ペテルブルグで刊行されたのでめる.

この刊行の年 (1803年) には石巻の漂流民10 名がイルクーツクからペテルブルグによばれて アレクサンドル一世に謁見し, その結果, 津田 夫, 儀兵衛, 左平, 太十郎の 4 名が 8 月クロン シュタットを出帆して，南アメリカ南端をまわ って翌年長崎に帰るのであるが，その時遁花秘 訣原書が刊行されていたかどらか訳者には不明 である。帰国後彼らは大梘玄沢（彼は 4 名のつ たえるロシア情報を「環海異聞」にまとめた） に種痘については何もつた觉ていない。ついで ながら彼らより10年前にロシアから帰った大黒 屋光太夫は桂川甫周に「彼邦〔ロシア〕にては 專占種痘の法を用引。午の法はよき痘瘡の膿を

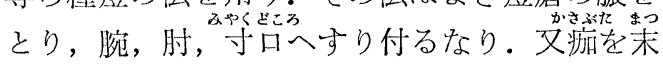
にして鼻の孔に吹いる，と」とつたえている。 (隹井高孝・村山七郎編北㮛聞略, 265ページ). これはもちろん人痘法である。

さて私より適当な訳者がいることはたしかで あるが，この原書をロシアから将来した者が下 
北半島の川内村出身の身分のいゃしいエトロフ 島漁場番人・五郎治 ${ }^{2}$ であり，この五郎治に対 して私が少なから興味を扣ぼえていること， この原書の完全なタイトルを日本ではじめて紹 介し，それをモスクワの国立レーニン名称図書 館で見出し，そのマイクロフィルムを入手した のが私であること，德川時代を通じての最も偉 大な博言学者・馬場佐十郎に対して私が深い尊 敬の念をいだいていること—ここしたことか ら私は敢てこの医学文献を自ら訳して公表する ことにした。誤訳も少なくないと思らが後日訂 正を期したい.

\section{村山 七 郎}

1965年, 西独ルール大学客員教授として赴任する日 を目前にひかえて

\section{注}

（1）村山七郎, 日本最初の牛痘法文献の原書, 順 天堂医学雑誌第 11 巻第 2 号 (昭和 40 年 7 月), 109 116ページ.

（2）訳者が1965年10月はじめてそのコピーを見た 五郎治申上荒増 ( 1812 年. 函館市立図書館所蔵写 本. 整理番号 00299-311-5001) 飞上れば, 五郎 治はこの原書を1812年 2 月上旬，イルクーックの商 人の家でもらいうけ，さらにヤクーック，オホーツ クで医師について歩いて植疮瘕の術（牛痘法）を習 得した、日本人として牛痘法の技術を身につけた最 初の者は五郎治である.

$$
※-※-\%
$$

\section{「半痘普及により}

\section{天然庢感染を完全に遁れる方法」}

医学・博愛委員会の著作 皇帝の命令により印刷 サンクト・ペテルブルグに积い て国立医学協議会印刷所俘い て1803年

序

\section{目次}

牛痘の効用といろいろな長所について

牛痘反対説に対する反駁

牡牛に和ける牛痘について
人間に和ける偶然の牛痘について

痘感染の諸特質について

牛痘接種の最良の方法について

ぞんな時期に痘物筫を取るべきか

痘物筫の保存

牛痘の作用の時期と仕方

真性及び仮性接種牛痘の徴候

附図

\section{序}

人類がかかる病気のうちで，ペストをのぞけ ば,もちろん天然痘㴗ど荒廃させるもの, 殺人的 なものはない. 天然痘はもっとも恐ろしい戦争 よりも破滅的である。なぜなら戦争はらつうは 局所的であるにすぎないが，天然痘は多くの国

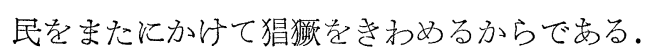
天然痘だけでも10年間に死んだ人々の身体が仮 によみかえるとしたら，我々の驚きはいかばか りであろらか。ヨーロッパの人口は 1 億 6 千万 人であるが，このろち毎年40万人以上がこの悪 霊の䬲食になっている。したがって1世代，つ まり33年の 万ちには1,400万人，1世 紀では 4,200万人が䬣食となるわけである。

計算を行なったところロシアでは天然痘で死 ぬ人が非常に多い。この伝染病にかかっても死 ぬとはかぎらないが，それにかかった人で，そ の害とか又は何らかの不快な結果を感じていな い人は稀で岕る。この伝染病は人間の生れつき の端麗な姿をゆがめてしまい, 青春の紅顔を青 ざめた死色に变えてしまう。らまれながらの貴 い視覚, 聴覚がしばしば失わ机, 生命の緒は非 常に弱ってしまうので, しばらくの間いろいろ な病気疾患のうらにくらしてから早かれ技矢か れ不可避的にこの病気の結果のためにたらきら れてしまうことになるのである。

天然痘の発端は 6 世紀だと見られている，次 第にこの病毒は多くの国々でひろまった。カム チャッカにこの病毒がもたらされたのはようや 
く1788年のことである。今日でもこの病毒を受 けない国々がある。たとえばカエナとかセント

・ヘレナ島とか。イタリヤの或る地方とかがそ らである。また他の国々ではこの病気は全く消 減してしまった。そこで天然痘は人間の本体に 具ったものではない，ということになる。つま り人間はその存在の発端からこの病毒の種を内 包していたわけでなく，この病毒の原因は感染 なのである。

天然痘病毒は源をどこに発したか，これは知 られていない。これについては次のこと以外に 知る必要は少しもない。つまり天然痘病毒は発 生し, 次いでその感染力によってひろまった， といらことである。病毒のひろまりは一部の人 々が考㝋るように空気によるものでなくて，他 の物体を媒介しているのである. 天然痘が普通 には伝染病として猖閅をきわめるということ は，多分，天然痘と同時に猖獭するも万も万の 伝染病に【痘〕物質が付着してこれらの伝染病 と一緒にひろまるためであろう。

そこで何故伝染病が或いは少なく, 或いはひ ぞく破滅的であるか, が理解される. 以上少し わき道に先れたが，わきみらをしたわけは，多 くの人々が未だに先入見をいだいで特り，「人 間は必ず天然痘にかからなくてはならず, 癒る か癒らないかは運命による。」と考兄ているか らである。こうした先入見は人痘接種普及の邪 魔となり，人痘よりはるかに有益な牛痘接種に も同じく邪魔となるであらう。

道德論から見て, 創造主が罰として代々，人 類絶隇の病気，伝染病に被造物をかからせるよ らにしたとは，考觉られない，天然痘について 言えることは，同じく例外なしに凡ての病気に も言えることであり，それどころか，放蕩から 生じる病気についてすら言える〔これらは神楞 ではない】。否，人間は，そんなため炕〔神罚 をうけるために了生れたのではない。人間はあ
らゆる理性的なこと，善良なこと，優美なこ そ, 高雅なことの出来る魂も, 情欲や悪い感化 に屈する魂も持つている。また身体も，有機的 に長寿と健康を保つょうに出来ているが，また 内外の善事, 悪事加多くの変化, 病気, 早死 をこうむるのである。公平無私な良識は歴史を 鑑とすべきである。良識は峳らゆる害を弱め， できるかぎり害を遠ざけることを歴史から学ぶ のである、我々は，完全には証明されてないき わめて稀な場合をのぞいて，一度天然痘にかか った者が二度とかからないことを知っている。 何故なら, 身体のこの感染傾向は一度身体に行 なわれた作用によって全く根絶されてしまらか ら.このことは人痘接種によって証明された し, 今やもっと有力に牛痘接種によって証明さ れた。牛痘によって普通の天然痘感染をふせ ぎ，予防できることが経験でたしかめられてい るとき, 牛痘物質が身体の天然痘感染傾向を根 絶する有力な力をもつことを, あれこれ理屈を のべて信じまいとするのは何のためか.

18世紀は特記すべき世紀であるが，その末に 扣ける最も重要な, そして全人類を救済する発 見として挙げるべきものは，天然痘疾患にくら ベてはもちろんのこと, 接種人痘にくらべてさ えも，きわめて軽微な病気〔牛痘法〕が認識さ れたことである。この病気の発作はらつ5局所 的にすぎず，大した痛みをひき抏こさず，健康 も美容もそこなわない，医師，薬品の助けをほ とんど必要とせず, 今日まで一人の人間をも殺 すことなく, 却って, 恐るべき天然痘感染をる せぐ確かな手段となっている。

我々は，この説明書を読み終って読者諸賢が 以上のことを確認するものとかたく期待してい る。そして読者諸賢が牛痘接種から生れる凡て の利益を尊重するならば, この真理に対するあ らゆる反対をららすてて, 両手をひろげて, こ の賞讃すべき救助手段〔牛痘接種〕を5け入れ るだろう。子を愛するどんな親も，この慈善的 
な発見を活用するだろう。恐れと疑いは消える だろう。この接種に反対する一日，一時間が無 駄と世間は見るだろろ。

かわいそ弓な多くの人々はこの病気のために 健康, 感覚を失い, 四肢の一部が役立たなくな り，有益に人生を和くることができなくなり， 社会の慈善をろけなければならなくなっている ので，そこで皇帝陛下〔アレクサンドル一世〕 からこのような不幸を減らすのに役立つ御下賜 金を受けた〔医学・博愛〕委員会はこの著作を 発行することを必要とみとめた。この著作は天 然痘から生ずる恐るべき害悪をま欢れる最も きさめのある手段〔牛痘接種〕を説明すること を目的とするものである。

\section{牛痘の効用といろいろな長所について}

ひろく行なわれた実験，とくにイギリス，ド イッ，フランス，执よび当のロシアに执いて牛 痘接種について行なわれた実験は, 牛痘が普通 の接種人痘と同じょ5に，天然痘第 2 次感染を 永久に根絶してしまうことを示している。

人痘接種は発作を軽くし，天然痘とくらべて この病気の死亡率を非常に減らした. しかし生 命, 健康, 美容が失われる危険は全く去ったわ けでなかった。しばしば非常にはげしいけいれ 几を伴って痘が出た。患者の全身は痘物質の破 滅的な外皮でつつまれた。午の上，悪臭の発汗 でよごれた空気，病児のうめき，不眠を目のあ たり見ては，もちろん両親は非常に苦しみ，愛 児に人痘を接種したことをのろい，悔い，愛児 の苦悩の罪は我にありと考えるのであった。こ うした両親の多くは，愛児がしばしば死んでし まうのを見て，慰められようもないのであっ た. 発疹の状態が良好で, 痘が少なくてよく熟 するような場合でも，すきま風にあたるとか， 不明の病因があると, 痘は一力所に集中して, はげしいけいれんを起して死んでしまう。今ま
での良好な経過も水の泡となる。肺炎, 呼吸困 難, その他の突然の結果が，急死など夢想だに されないよろな時に愛児の生命をらばってしま うことも時折あった. 何故なら，らまく利用さ れても, 常に人痘接種をうけた 1,000 名につき 5 名が死に, 通常20名の5ち 1 名が重症になる からである。そこで 10 万名の児童の5ち多分 500 名が死に，5,000名が重症となり，又はその 後長い間，その〔雭〕結果に苦しんだのであ る、軽卒にこれを行なったときや，経験のない 医師などが，こともあろうに他の伝染病がはや っているよろな時に，適当な知識もなく【人】 痘接種をしたときにも, これらの犠牲者の数は 増加した. 彼らは接種によって発作が起こると き，患者を適当に取扱うしかるべき知識を持ち あわせていないのである。

このような恐ろしい発作は稀だとはいって も，多くの人々はそのために，これ核ど有益な 人痘接種をさしひかえた。それだけに一層誰で も牛痘接種を喜んで希望するだろう。何故な ら，文明国に和けるその作用を観察したすべて の人々が一致して証言するところによれば，ま た我々自身の実験に上れば，その経過は非常に 軽微で, 微熱をともなら以外, 何の発作もな く,それによってひき起こされる病気は人痘の ひき扣こすものとくらべものにならないくらい 軽いからである，前に〔人痘接種の場合に〕挙 げたような発作はひとつも記録されていない し, 病気は決して危険でなかった。なるほど小 さな発疹が見られることもあるが，とれは大し たものでなく，健康はもとより，皮膚も害なわ れないのである。

接種される牛痘は決して有害な結果を残さな い.これに反して人痘はしばしば急死をともな い，徐々に生命を破壊する発作一一たとえば骨 疽とか肺病とか—をともなう。

虚弱児や，他の病気になやむ児童は必ずしも 
容易に人痘接種に耐えない。これは前述の通 り。これに反して，幾度も行なわれた観察によ ると，そのような児童が牛痘を接種されるとそ の健康状態はずっとよくなる。かくて，この微 熱は身体器官内で良好な変化をひき抢こし，乙 ばしば或る疾患を治療し，また病気にかかりや すい傾向をなくしてしまうである。

妊娠自体も，またこれまでは非常に危険とみ なされていた崡の生えも，牛痘接種の妨げとな らないし，その正常な経過を少しも妨げるもの でない.

牛痘と一緒に家畜特有のその他の病気又はそ の素質がうつされるかも知れないという間違っ た考觉を懷く者がある。この痘は牝牛の乳房の 特別な病気であるから，決して牝牛の他の病気 を伴わない，そんなことに注意を向ける必要は ない、なぜなら，すでに牝牛から痘物質をとる のは稀であって，牛痘を接種された小児の身体 から取るからである。

季節も少しも牛痘接種の妨げとならない。麻 疹やそれに類する発疹のようなありふれた伝染 病でさえも，妨げとならない。何故なら経験の 示すところによれば，牛痘はいつでも接種でき るしまた，もし他の病気が合流すれば，牛痘 の経過は他の病気が経過するまで中断される か, 又は牛痘が過ぎるまでこれらの病気の経過 が停止されるからである。気候の相異も牛痘に 大した影響を及ぼさない。

病気の経過は天気にも気候にも左右されな い。っとも暑小土地でも, もっとも寒い土地 でも, ヨーロッパでもアメリカでも, 経過は一 様である。

最も重要なことは，しばしば【接種〕人痘が 伝染病であるのとは異って，牛痘が伝染病でな いことである。なる汪ど，多くの人痘接種者が 助かっている。しかし感染をとどめるのはむず
かしく，感染による死亡率は増大した。イギリ スでは人痘接種実施後, 以前よりも 1,000 名に つき17名多く死亡した。ロンドンだけでも人痘 接種実施後42年間にその前の42年間上り 24,000 名多く死亡した (Vollständige Abhandlung über die Kuhpocken von F. G. A.

Buchholz, Berlin 1802. Das Wissenswürdigste von den Kuhpocken von Ferdinand Schulz, Berlin 1801. F・G・A ブ フホルッ「牛痘に関する完全な論述」ベルリ ン, 1802.フェルディナント・シュルツ「牛痘 必携」ベルリン 1801 年).

このような凡ての苦情は今ではあり得ない。 牛痘を接種された者は，きわめてたやすく天然 痘から予防される。周囲の者は一人として天然 痘に感染せず，流行的な天然痘はなくなった。

天然痘のように破滅的な病気を根絶する以上 に望をしいものはない。

天然痘根絶の手段を発明し提案しょうとつと めた凡ての人は，感謝されてしかるべきであ る。しかし彼らが努力をはらったにもかかわら ず，この災厄を減らす上に多大の困難が今日ま で残っていた。そしてこの災厄を完全にまぬが れることは不可能と見られていた。乙かし牛痘 が発明されて以来，この炎厄を完全にま攼れれ る方法が発見されたのである。その最大の長所 はありられた天然痘を絶隇する希望を我々に与 えたことにあることは確かだ。もし，いたると ころで牛痘が実施され，ぞの赤ん坊にも牛痘が 接種され，他方，人痘接種がいた方亡こ方莎

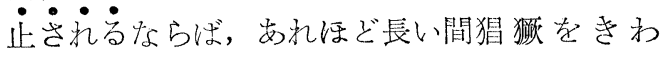
め，しぼしば無残に数百万の人間をくいつくし た天然痘は必ず全滅するはずである。

こういうわけで, 感染疮ひき括こさない全く 新しい物筫が天然痘感染の傾向を根絶するで女 ろう。この物質は人間に全く危険がなく，たと 
えば 1 〜 年というあまり長くない期間に全面 的な接種を行なえば天然痘感染はこの世から消 滅するだろう。凡ての医師, 哲学者たち, 人類 の真の友はこれを願っているし，また願うべき だ。これは単なる痛快な夢にすぎないのではあ るまいか。単なる善良な願望にすぎないのでは あるまいか。いな!亮の実現は可能であるばか りか, 或る人々が考觉るほどにはさずかしくな いから，右のような瞉慮は不要である。二つの 首府 [ペテルブルグとモスクワ]やその他の大 都会にはかなり多くの善意の医師が括り，めい めいがその市区に执いて種痘普及によって天然 痘根絶にすすんで協力することに同意するであ ろう。県では医師会がそれを配慮すべきであ り, 郡の都会では郡医師たちが，村では僧侶や 学校教師たちが真にキリスト教的なこの事業を 行ならべきである。また学識ある助産婦, 地 主, 管理人, あらゆる戸主, 主婦も行ならべき である。一般に僧侶は幾手幾方といら同胞の生 命を救うこの有益な手段の助成を神聖な義務と みなして，信仰及び理性の規則によって，この 偉大な事業をらけいれるように人々をしむける べきである。僧侶はとの信徒団に対して，現世 の人間にとって最も大切なことの一つは，完全 な健康一一それはあまりにもしばしば天然痘に よって奪われている—であること，また人々 の生命を維持する手段を講じないことは人々を 殺すに等しいことを説得することができる，僧 職者が行ならこのような世話は, 当然, 彼らの 高い地位の崇高な使命にふさわしいるのであ りまた政治的な側から見れば帝国の福祉はそ れによって大いに增大するであろう。

\section{牛痘接種反対説に対する反駁}

牛痘があたかも永久に感染を予防するもので ないかのように言われたり書かれたりした。言 ったり書いたりするのは人々の勝手だ〔しか し〕これ[永久に感染を予防するか否か〕は, 経験によっての久解決すべきであった。われわ れは経験の語るところに耳をかたむけそれに従 らべきである。ジェンナーは，信頼の㧠けるそ の報告に括いて, 牛痘にかかってから25年, 27 年, 31年, 53年の間, きわめてしばしば感染に さらされても感染しなかった人々を紹介した。 同じような経験はへルワクも提供している。こ の種の多くの場合にイギリスの農場主たちが自 分の子供たちや乳売り女のことを報告してい る. ホルシュタインではこのような反対説〔牛 痘が永遠に感染を予防するものでないといら反 対説】が間違っていることが最も確実に証明さ れている、〔また論難者】日く，牛痘実験は未 だあまりにも少数で，この物は我々にとってき わめて新しいるのだ，と、しかしその反対のこ とを確かめるために, 第 2 次接種が多数行われ なかったろらか。牛痘接種をうけ, 感染にさら され又は猖獭をきわめる悪質の天然痘流行にさ らされた凡ての人々は，この不信がどんなに間 違ったものであるか，またこの反対論がどんな に無根拠のものであるかを証明していないだろ らか。イギリスでは，わずか 10 万人が牛痘を 接種されたとき， 8,000 人に対してこの動作が くり返され, 彼らは久な最も悪質の, 当時猖猯 をきわめた伝染病にさらされたが，二度感染し た者は一人もなかった。このような実験は，何 らかの空理空論よりも, また単に抽象的思弁に もとづいた凡ゆる懐疑よりも尊重すべきではな いか。

(๖づく) 